\title{
C4 Vertebra
}

National Cancer Institute

\section{Source}

National Cancer Institute. C4 Vertebra. NCI Thesaurus. Code C32242.

The fourth of the seven cervical vertebrae. 